\title{
PENGARUH PENGGUNAAN MEDIA BIG BOOK WRITING TERHADAP KETERAMPILAN MENULIS BAHASA INDONESIA SISWA KELAS 5 SD NEGERI 1 PILANGBANGO MADIUN
}

\author{
Dian Permatasari Kusuma Dayu, Liya Atika Anggrasari
}

\section{IKIP PGRI MADIUN}

Email: dayuprasanda12@gmail.com

\begin{abstract}
ABSTRAK
Keterampilan Menulis adalah salah satu kemampuan berbahasa yang harus dikuasai oleh siswa. Menumbuhkembangkan untuk berani mengekspresikan gagasan atau gagasan siswa dalam bentuk tertulis dapat dikembangkan melalui pendidikan. Namun, sayangnya habituasi ini tidak ditanggapi secara serius dalam sistem pendidikan, sehingga budaya penulisan pada siswa tetap rendah dan masih banyak siswa yang merasa kesulitan untuk melakukan penulisan cerita. Tujuan menulis keterampilan di sekolah adalah agar siswa dapat berbicara bahasa Indonesia untuk mengembangkan ide atau gagasan secara tertulis melalui esai yang mereka buat. Salah satu media yang dapat meningkatkan media pembelajaran menulis adalah Big Book Writing. Media Big Book Writing adalah salah satu media yang dapat merangsang siswa untuk menulis. Big Book Writing adalah buku bacaan dengan ukuran, teks, dan grafis yang hebat.
\end{abstract}

Kata Kunci: Keterampilan Menulis, Media Pembelajaran, Big Book Writing

\begin{abstract}
Writing Skills is one language skills that must be mastered by the student. Civilizing expressing ideas or students' ideas in written form can be developed through education. However, unfortunately this habituation is not taken seriously in the education system, so that the culture of writing in the student still low and there are still many students who find it difficult to carry out writing stories. The purpose of writing skills in school is that the students have the ability to speak Indonesian to develop an idea or ideas in writing through essay they create. One media that can enhance learning media wrote that the Big Book Writing. The Media Big Book Writing is one medium that can stimulate students to write. Great Big Book Writing a book is a book reading with the size, text, and graphics are great.
\end{abstract}

Keyword: Writing skills, Learning Media, Bigbook Writing 


\section{A. PENDAHULUAN}

Pada dasarnya, orang menulis karena ingin menyampaikan gagasan, pikiran, dan perasaannya kepada orang lain melalui bentuk tulisan, agar orang lain mengetahui apa yang menjadi pikiran dan perasaanmya. Hal itu sejalan dengan pendapat Tarigan yang mengemukakan bahwa menulis merupakan suatu keterampilan berbahasa yang dipergunakan untuk berkomunikasi secara tidak langsung, tidak secara tatap muka dengan orang lain ${ }^{22}$. Menulis merupakan suatu kegiatan yang produktif dan ekspresif. Produktif berarti menghasilkan suatu produk tulisan dan ekspresif berarti mengungkapkan pikiran dan perasaan yang ada pada diri seseorang.

Ada kalanya seseorang hanya bisa menyampaikan gagasan, perasaan, dan pikirannya secara tidak langsung, dan salah satu cara menyampaikannya yaitu dengan sebuah tulisan. Hal tersebut membuat seseorang sebaiknya memiliki keterampilan menulis dengan baik, agar apa yang ingin disampaikan dapat tersampaikan dengan baik, sehingga tidak menimbulkan kesalahpahaman. Keterampilan menulis seharusnya juga dimiliki oleh siswa. Menulis merupakan salah satu kegiatan pembelajaran yang penting bagi siswa. Dengan menulis, siswa dapat menuangkan ide, pikiran, dan perasaan untuk memberikan informasi kepada orang lain dalam bentuk tulisan. Dengan menulis, siswa dapat menumbuhkan kreativitasnya. Menulis mampu membuat siswa haus akan ilmu pengetahuan karena menulis memerlukan kepiawaian dan kecerdasan yang membuat siswa akan terus belajar agar mampu menulis dengan baik. Keterampilan menulis tidak datang begitu saja, tetapi perlu adanya

22 Tarigan, H.G. Menulis Sebagai Suatu Keterampilan Berbahasa (Bandung: Angkasa Bandung, 2008), Hlm. 3. proses belajar dan latihan. Keterampilan menulis perlu diasah agar menghasilkan tulisan yang indah. Oleh karena itu, keterampilan menulis haruslah dilatih sejak dini, agar menghasilkan manusia yang kreatif dalam menghasilkan sebuah tulisan.

Mata pelajaran bahasa Indonesia secara umum memiliki tujuan agar peserta didik memiliki kemampuan untuk: (1) berkomunikasi secara efektif dan efisien baik secara lisan maupun tulis; (2) memahami bahasa Indonesia dan menggunakannya dengan tepat dan kreatif untuk berbagai tujuan; (3) menggunakan bahasa Indonesia untuk meningkatkan kemampuan intelektual, serta kematangan emosional dan sosial; (4) berkomunikasi secara efektif dan efisien sesuai dengan etika yang berlaku, baik secara lisan maupun tulis; (5) menikmati dan memanfaatkan karya sastra untuk memperluas wawasan, memperhalus budi pekerti, serta meningkatkan pengetahuan dan kemampuan berbahasa; (6) menghargai dan membanggakan sastra Indonesia sebagai khasanah budaya dan intelektual manusia Indonesia ${ }^{23}$. Ruang lingkup pembelajaran bahasa Indonesia dalam Standar Isi dan Standar Kompetensi Lulusan untuk satuan pendidikan dasar SD/MI mencakup empat aspek, yaitu mendengarkan, berbicara, menulis dan membaca ${ }^{24}$. Keempat aspek bahasa ini tidak dapat dipisahkan satu sama lain dan memiliki keterkaitan yang sangat erat. Keterampilan bahasa tersebut dapat melatih siswa menggunakan bahasa untuk berkomunikasi baik lisan maupun tertulis.

Keterampilan Menulis merupakan salah satu keterampilan berbahasa yang harus dikuasai

23 Depdiknas. Peraturan Menteri Pendidikan Nasional Nomor 22 Tahun 2006 Tentang Standar Isi untuk Satuan Pendidikan Dasar dan Menengah (Jakarta: Depdiknas, 2006), Hlm. 120.

24 ibid 
oleh siswa. Pembudayaan menuangkan gagasan atau ide siswa dalam bentuk tulisan dapat dikembangkan melalui pendidikan. Namun, sayang pembiasaan ini belum ditanggapi dengan serius dalam sistem pendidikan, sehingga budaya menulis pada kalangan siswa masih rendah dan masih banyak siswa yang mengalami kesulitan untuk mengerjakan penulisan cerita. Tujuan keterampilan menulis di sekolah adalah agar siswa memiliki kemampuan berbahasa Indonesia yang dapat mengembangkan gagasan atau ide secara tertulis melalui karangan yang mereka buat.

Melihat pentingnya peranan menulis bagi kehidupan, maka dalam kurikulum, terdapat standar kompetensi menulis. Begitu juga di sekolah dasar juga terdapat standar kompetensi menulis. Hal itu menunjukkan bahwa keterampilan menulis sangat penting dimiliki siswa. Keterampilan menulis harus dilatih sejak dini, karena keterampilan menulis tidak dapat dikuasai dengan tiba-tiba tetapi perlu dilatih dari dini. Dengan adanya standar kompetensi tersebut di sekolah dasar, diharapkan peserta didik mampu menulis secara baik dan kreatif dari sejak dini.

Mengajarkan menulis bukanlah hal yang mudah. Banyak siswa kelas sekolah dasar yang kemampuan menulisnya masih rendah. Masih banyak siswa sekolah dasar yang masih kesulitan untuk menulis. Hal tersebut terjadi karena minat siswa untuk menulis masih rendah. Selain itu, tahapan berpikir siswa SD masih berada pada tahap operasional konkrit. Hal itulah yang seharusnya dilakukan perbaikan pembelajaran menulis disesuaikan dengan tahap kemampuan siswa. Apabila siswa SD tahapan berpikir mereka masih berada pada tahap operasional konkrit, maka dalam pembelajaran guru harus menjelaskan dengan tahapan operasional konkrit.
Sampai saat ini, sebagian besar guru masih melaksanakan pembelajaran dengan media pembelajaran yang kurang menarik, sehingga dalam pembelajaran menulis sangat kurang menyenangkan dan membuat siswa sangat bosan dan susah dalam mengeluarkan ide kreativitas menulisnya. Selain itu siswa sangat jarang untuk memilih topik cerita sendiri. Dalam proses kegiatan menulis di sini Guru menentukan beberapa judul/ topik, lalu menugasi siswa memilih satu judul sebagai dasar untuk menulis. Yang diutamakan adalah produk yang berupa tulisan. Pembahasan karangan jarang dilakukan.dan penggunaan mendia yang masih sangat kurang dan menarik. Dengan kegiatan pembelajaran seperti itu, siswa mengalami kesulitan dalam menulis karena keharusan mematuhi judul/ topik yang telah ditentukan guru.

Hal itu menjadikan kreativitas siswa tidak dapat berkembang secara maksimal. Hakikatnya, kesulitan menulis tersebut berkaitan dengan apa yang harus ditulis dan bagaimana cara menuangkannya dalam bentuk tulisan. Dampak negatif dari model pembelajaran itu adalah kurangnya motivasi siswa untuk menulis sehingga keterampilan menulis siswa pun rendah. Paparan di atas mengisyaratkan bahwa keterampilan menulis perlu ditingkatkan. Untuk meningkatkannya, guru harus memperbaiki model pengajaranya. Kemudian masalah yang sering terjadi dalam pelajaran menulis cerita adalah kurang mampunyai siswa menggunakan bahasa Indonesia yang baik dan benar. Hal tersebut dapat dilihat pada pilihan kata yang kurang tepat, kalimat yang kurang efektif, sukar mengungkapkan gagasan karena kesulitan memilih kata atau membuat kalimat, bahkan kurang mampu mengembangkan ide secara teratur dan sistematik, di samping kesalahan masalah ejaan 
Salah satu cara mengoptimalkan proses pembelajaran menulis dan meningkatkan motivasi siswa dalam menulis, yaitu dengan memberikan media pembelajaran yang menarik sehingga mampu meningkatkan minat siswa dalam menulis. Selain itu, media tersebut harus dihubungkan dengan hal yang nyata agar siswa sekolah dasar mudah dalam memahaminya. Media pembelajaran penting untuk diberikan kepada siswa SD karena media pembelajaran dapat merangsang pola pikir siswa. Hal tersebut sejalan dengan pendapat Mudiono (2010) yang menyatakan bahwa media pembelajaran adalah segala sesuatu yang dapat menyalurkan pesan, dapat merangsang pikiran, perasaan, dan kemauan peserta didik sehingga dapat mendorong terciptanya proses belajar pada diri peserta didik.

Berdasarkan uraian di atas maka perlu membuat sebuah media yang dapat membangkitkan keinginan dan minat yang baru, membangkitkan motivasi dan rangsangan kegiatan belajar siswa. Salah satu media pembelajaran yang dapat meningkatkan pembelajaran menulis, yaitu media Big Book Writing. Media Big Book Writing merupakan salah satu media yang dapat merangsang siswa untuk menulis. Buku Besar (Big Book) adalah buku bacaan yang memiliki ukuran, tulisan, dan gambar yang besar. Big Book dapat berisi cerita yang dipadukan dengan gambar pop up untuk menarik minat baca siswa. Pop Up merupakan gambar yang memiliki bagian yang dapat bergerak atau berunsur 3 dimensi. Selama pembelajaran siswa akan lebih aktif, kreatif, saling kerjasama, dan termotivasi dalam belajar. Dengan demikian pembelajaran yang berlangsung akan lebih bermakna.

\section{B. METODE PENELITIAN}

Penelitan dilakukan di SD Negeri 1 Pilangbango Madiun tahun ajaran 2015/2016.
Penelitian ini bersifat kuantitatif kategori penelitian eksperimen. Penelitian ini menggunakan One-Group Pretest-Posttest Design. Sebelum memberikan treatment, peneliti melakukan pretest guna melakukan diagnosis awal mengenai keterampilan menulis cerita bahasa Indonesia. Kemudian setelah memberikan treatment, peneliti memberikan post test untuk mengukur keterampilan menulis cerita bahasa Indonesia, sehingga dapat diketahui pengaruh penggunaan Media Pembelajaran Big Book Writing terhadap keterampilan menulis cerita bahasa Indonesia.

Untuk variabel penelitiannya terdiri dari variabel terikat dan variabel bebas. Variabel terikat adalah keterampilan menulis dan variabel bebasnya adalah media Big Book Writing. Teknik sampel yang digunakan peneliti adalah teknik Cluster Random sampling. Suharsimi Arikunto menjelaskan teknik Cluster digunakan bilamana populasi tidak terdiri dari individu-individu melainkan kelompok ${ }^{25}$.

Penelitian ini bersifat eksperimen, karena hasil penelitian akan menegaskan kedudukan hubungan kausal antara variabel-variabel yang akan diteliti, tujuannya terletak pada penemuan fakta-fakta penyebab dan akibat tentang perbedaan media Big Book Writing dengan media konvensional. Dalam penelitian ini untuk mendapatkan data yang menunjang pemecahan masalah yang penulis ajukan, penulis menggunakan dua teknik pengumpulan data, yaitu angket dan tes. Angket digunakan untuk mengumpulkan data tentang kreativitas belajar dan tes digunakan untuk keterampilan menulis cerita bahasa Indonesia.

25 Arikunto, Suharsimi, Prosedur Penelitian: Suatu Pendekatan Praktik (Cetakan Kelima belas), (Jakarta: Rineka Cipta, (2013), Hlm. 185. 
Teknik analisis data ini menggunakan perhitungan statistik yang datanya berupa data kuantitatif, yaitu suatu data yang bisa diukur, dimana variabel bebas dan variabel terikatnya akan dicari korelasinya sesuai dengan rumusan masalah di atas. Teknik analisis data dalam penelitian ini menggunakan uji normalitas, uji homogenitas, dan uji hipotesis yang menggunakan uji t.

\section{PEMBAHASAN}

\section{Media Pembelajaran}

Media pembelajaran merupakan salah satu alat yang digunakan untuk membantu proses pembelajaran. Guru akan lebih mudah memberikan penjelasan terkait materi yang disampaikan dengan menggunakan media pembelajaran. Siswa mampu memahami materi yang sulit dengan bantuan media.

\section{AECT (Association for Education} Communication Technologi memberikan batasan media sebagai segala bentuk dan satuan yang digunakan orang untuk mengeluarkan pesan atau informasi. Gerlach dan Ely mengatakan bahwa media adalah manusia, materi, atau kejadian yang membangun kondisi yang membuat siswa mampu memperoleh pengetahuan, keterampilan, atau sikap ${ }^{26}$.

Media pembelajaran menurut Rudi Susilana $^{27}$ merupakan suatu wadah dari pesan, kemudian materi yang ingin disampaikan adalah pesan pembelajaran, tujuan yang ingin dicapai adalah proses pembelajaran. Menurutnya, penggunaan

26 Arsyad, Azhar, Media Pembelajaran, (Jakarta: PT Grafindo Persada, .2009), Hlm. 3.

27 Susilana, Rudi dan Cepi Riyana., Media Pembelajaran, (Bandung: Jurusan Kurikulum dan Teknologi Pendidikan, FIP, UPI, 2008), Hlm. 6 . media secara kreatif akan memperbesar kemungkinan bagi siswa untuk belajar lebih banyak, memiliki pengalaman belajar yang beragam, dan meningkatkan penampilan dalam melakukan ketrampilan sesuai dengan yang menjadi tujuan pembelajaran.

Media pembelajaran pada hakikatnya merupakan jembatan antara guru dan peserta didik agar pembelajaran menjadi efektif. Seperti yang digambarkan dalam kerucut pengalaman Edgar Dale dalam Susilana dan Riyana $^{28}$, yaitu "pengetahuan akan lebih abstrak apabila pesan hanya disampaikan melalui kata verbal yang memungkinkan terjadinya verbalisme.” Artinya materi yang disampaikan oleh guru akan lebih konkrit dan mudah dipahami oleh peserta didik dengan bantuan media.

Berdasarkan uraian di atas maka dapat diambil kesimpulan bahwa media pembelajaran merupakan salah satu komponen penting dalam menyampaikan suatu materi yang disampaikan komunikator (guru) kepada komunikan (siswa) untuk dapat memberikan rangsangan yang sama, memberikan pengalaman dan persepsi yang sama dalam kegiatan belajar mengajar untuk mencapai tujuan pembelajaran.

\section{Manfaat Media Pembelajaran}

Penggunaan media pembelajaran harus sesuai dengan kebutuhan pembelajaran. Menurut Jamil Suprihatiningrum ${ }^{29}$, manfaat media pembelajaran: 1) Fungsi artensi, menarik perhatian siswa dengan menampilkan sesuatu yang menarik dari media tersebut; 2) Fungsi motivasi,

\section{Ibid. Hlm.9.}

29 Suprihatiningrum, Jamil, Guru Professional, (Yogyakarta: Delta Press, 2013), Hlm. 320. 
menumbuhkan kesadaran siswa untuk lebih giat belajar; 3) Fungsi afeksi, menumbuhkan kesadaran emosi dan sikap siswa terhadap materi pembelajaran dan orang lain.

Manfaat media dilihat dari psikologi di atas memiliki beberapa penyempurnaan dengan melihat manfaat media secara umum yang dipaparkan oleh Rudi Susilana, antara lain: 1) Memperjelas pesan agar tidak terlalu verbalitas, 2) Mengatasi keterbatasan ruang, waktu, tenaga dan daya indera, 3) Menimbulkan gairah belajar, interaksi lebih langsung antara murid dengan sumber belajar, 4) Memungkinkan anak belajar mandiri sesuai dengan bakat dan kemampuan visual, auditori, dan kinestetiknya, 5) Memberi rangsangan yang sama, mempersamakan pengalaman dan menimbulkan persepsi yang sama ${ }^{30}$.

Berdasarkan uraian di atas dapat disimpulkan bahwa media pembelajaran memiliki manfaat yang mampu menarik perhatian siswa, memotivasi siswa dan mampu mengatasi keterbatasan ruang sehingga anak akan belajar secara mandiri sesuai dengan minat dan bakat. Media pembelajaran juga akan mengantarkan siswa untuk mencapai tujuan pembelajaran yang diinginkan.

\section{Klasifikasi Media}

Klasifikasi media ini diperlukan untuk mengetahui secara detail media yang sesuai dengan tipe belajar yang dimiliki siswa, sehingga memudahkan guru dalam melaksanakan penerapannya yang disesuaikan dengan kebutuhan siswa.

30 Susilana, Rudi dan Cepi Riyana, Media Pembelajaran, (Bandung: Jurusan Kurikulum dan Teknologi Pendidikan, FIP, UPI, 2008). Hlm.9.
Menurut Rudi Susilana media diklasifikasikan menjadi tujuh kelompok, yaitu: (a) kelompok grafis, bahan cetak, dan gambar diam; (b) kelompok media proyeksi diam; (c) kelompok media audio; (d) kelompok media audio; (e) kelompok media gambar hidup/ film; (f) media televisi; (g) kelompok multimedia ${ }^{31}$.

Adapun menurut Rusman, dkk. ${ }^{32}$ terdapat lima jenis media yang dapat digunakan untuk proses pembelajaran, yaitu (a) media visual (b) media audio (c) media audio-visual (d) media penyaji (e) media objek dan media interaktif. Dari kelima klasifikasi media ini, media yang paling sering digunakan adalah media visual dan audio visual yang mampu menarik perhatian siswa dalam pembelajaran. Media yang memiliki berbagai macam klasifikasi yang telah dipaparkan pada dasarnya memiliki pengaruh yang besar dalam proses belajar peserta didik jika media tersebut digunakan sesuai secara tepat sasaran. Siswa memiliki tipe balajar yang berbeda, sehingga guru perlu menyesuaikan media yang digunakan dalam proses pembelajaran.

\section{Media Big book Writing}

Kasihani K.E. Suyanto ${ }^{33}$ menjelaskan bahwa Big Books Writing merupakan salah satu media yang disenangi anak-anak

31 Susilana, Rudi dan Cepi Riyana, Media Pembelajaran, (Bandung: Jurusan Kurikulum dan Teknologi Pendidikan, FIP, UPI, 2008). Hlm.13.

32 Rusman, Kurniawan, Deni, Riyana, Cepi, Pembelajaran Berbasis Teknologi Informasi dan Komunikasi Mengembangkan Profesionalitas Guru, (Jakarta: Rajagrafindo Persada, 2012), Hlm.63.

33 Suyanto, Kasihani K.E., English for Young Learners, (Jakarta: PT Bumi Aksara, (2007), HIm. 104. 
dan dapat dibuat sendiri oleh guru. Buku berukuran besar ini biasanya digunakan untuk anak kelas rendah. Di dalamnya berisi cerita singkat dengan tulisan besar diberi gambar yang warna-warni. Anak bisa membaca sendiri atau mendengarkan ceritanya dari guru. Lynch dalam Ika dan Bambang $^{34}$ mengatakan bahwa Big Books dapat menjadi motivasi yang kuat untuk belajar tentang pengucapan kata, bentuk dan jenis kata seperti kata majemuk, kata kerja, singkatan, maupun sajak. Kebiasaan dalam mendengarkan atau membaca cerita akan menambah kosakata. Dari dua pendapat di atas, dapat disimpulkan bahwa Big Books merupakan media untuk belajar pengucapan kata, bentuk maupun jenis kata yang digemari oleh anak-anak. Big Books digunakan di kelas rendah yang berisi cerita singkat disertai gambar.

Keuntungan menggunakan Big Books Writing menurut Mohana Nambiar ${ }^{35}$ yaitu sebagai berikut: a) karena Big Books berukuran besar, siswa dapat melihat gambar jalannya cerita dengan jelas, seperti saat mereka membaca buku sendiri. Hal tersebut tentu akan menarik bagi siswa; b) Big Books Writing membuat siswa menjadi lebih fokus terhadap bahan bacaan dan juga guru. Biasanya jika guru menggunakan buku biasa, siswa akan asyik bermain sendiri. Namun, dengan Big Books writing siswa akan tertarik dan mau mendengarkan cerita

34 Fitriani, Ika dan Bambang Yudi Cahyono. "The Effectiveness of Implementing BigBook and Narrative-Scaffold on the Students' Achievement in Writing Narrative Texts." Jurnal Universitas Negeri Malang (Vol. 1 Nomor 1, 2012), Hlm. 9.

35 Nambiar, Mohana, "Early Reading InstructionBig Books in the ESL Classroom." Jurnal The English Teacher (Vol XXII, (1993), Hlm. 5. dari guru; c) siswa akan lebih mengerti dan memahami isi cerita dalam Big Books daripada buku bacaan biasa karena kata-kata yang terdapat dalam Big Books merupakan kata-kata sederhana. Siswa dapat mengikuti setiap kata yang diucapkan oleh guru dan mengetahui bagaimana penulisannya; d) Big Books Writing memfasilitasi siswa seakanakan melihat langsung cerita yang dibacakan guru. Siswa dapat merasakan jalannya cerita, dan Big Books Writing merupakan hal baru yang akan membuat siswa tertarik dan mempunyai rasa ingin tahu yang tinggi terhadap apa yang ada di dalamnya, sehingga siswa menjadi antusias dalam pembelajaran.

Karges dan Bones (melalui Susan dan Barbara, 2006: 493) menjelaskan karakteristik Big Books Writing, yaitu: a) cerita pendek sekitar 10-15 halaman yang melibatkan kepentingan peserta didik supaya mereka tertarik, b) berpola sehingga siswa mudah untuk belajar dan mudah diingat, c) gambar yang besar membantu siswa mengkonstruksi makna dari cerita, d) mengandung frase yang diulang-ulang dan mengandung kosakata yang sesuai dengan kosakata yang dimiliki siswa, e) sederhana, tetapi menarik dalam alur ceritanya, dan f) mengandung unsur humor.

Dari beberapa pendapat di atas, dapat disimpulkan bahwa Big Books merupakan buku cerita yang berukuran besar dengan gambar berwarna sehingga dapat menarik minat siswa untuk membaca dan cerita yang sederhana dan digunakan siswa untuk belajar membaca serta menambah kosa kata. Penggunaan Big Book dalam pembelajaran diharapkan mampu merangsang daya pikir dan imajinasi siswa sehingga mampu memunculkan ide-ide kreatif siswa yang 
dapat dituangkan dalam bentuk tulisan atau cerita.

\section{Keterampilan Menulis}

Menulis merupakan salah satu dari empat aspek keterampilan berbahasa. Keterampilan berbahasa yang lain adalah menyimak, berbicara, dan membaca. Menurut Burhan Nurgiyantoro (1987: 27), menulis dapat dikatakan keterampilan yang paling sukar. Bila dilihat dari urutan pemerolehannya, keterampilan atau kemampuan menulis berada pada urutan terakhir setelah kemampuan mendengarkan, berbicara, dan membaca. Jika dilihat dari sudut aspek keterampilan berbahasa, menulis merupakan kegiatan yang bersifat aktif produktif. Bagi siswa usia Sekolah Dasar menulis lebih cenderung pada kemampuan daya pikir. Hal itu senada dengan Mulyati (1998: 244) yang menyatakan bahwa menulis pada hakikatnya menyampaikan ide atau gagasan dan peran dengan menggunakan lambang grafis (tulisan). Gagasan atau pesan yang akan disampaikan bergantung pada perkembangan dan tingkatan pengetahuan serta daya nalar.

Sekurang kurangnya, ada tiga komponen yang tergabung dalam perbuatan menulis, yaitu: (1) penguasaan bahasa tulis, yang akan berfungsi sebagai media tulisan, meliputi kosakata, struktur kalimat, paragraf, ejaan, pragmatik, dan sebagainya; (2) penguasaan isi karangan sesuai dengan topik yang akan ditulis; dan (3) penguasaan tentang jenis-jenis tulisan, yaitu bagaimana merangkai isi tulisan dengan menggunakan bahasa tulis sehingga membentuk sebuah komposisi yang diinginkan. Sebagai bagian dari kegiatan berbahasa, menulis berkaitan erat dengan aktivitas berpikir. Keduanya saling melengkapi. Costa (1985: 103) mengemukakan bahwa menulis dan berpikir merupakan dua kegiatan yang dilakukan secara bersama dan berulang-ulang. Tulisan adalah wadah dan sekaligus merupakan hasil pemikiran. Melalui kegiatan menulis, penulis dapat mengkomunikasikan pikirannya. Dan melalui kegiatan berpikir, penulis dapat meningkatkan kemampuannya dalam menulis.

The Liang Gie (2005b: 7) menyatakan bahwa buah pikiran yang dituangkan penulis dapat berupa pengalaman, pendapat, pengetahuan, dan perasaan. Hasil perwujudan bahasa tulis itu menjadi buah karya tulis yang berupa karangan apa saja termasuk di dalamnya menulis baik faktawi maupun fiksi, baik pendek yang hanya beberapa lembar maupun yang panjang sampai berjilid-jilid, baik dalam corak puisi maupun prosa.

Menulis merupakan sebuah seni yaitu dalam menuangkan ide seorang pengarang ke dalam suatu tulisan itu bebas, sesuai dengan kreativitas dan daya seni seseorang. Kata seni mengandung arti "keahlian membuat karya yang bermutu atau kesanggupan akal untuk menciptakan sesuatu yang bernilai tinggi dan luar biasa. Menulis berarti menuangkan isi hati si penulis ke dalam bentuk tulisan, sehingga maksud hati penulis bisa diketahui banyak orang melalui tulisan yang dituliskan. Kemampuan seseorang dalam menuangkan isi hatinya ke dalam sebuah tulisan sangatlah berbeda dipengaruhi oleh latar belakang penulis. Dengan demikian mutu atau kualitas tulisan setiap penulis berbeda pula satu sama lain, tergantung dari keahlian dan daya kreativitas seseorang dalam menuangkan gagasannya menjadi tulisan. 


\section{HASIL PEMBAHASAN}

\section{Uji Normalitas dan Homogenitas}

Uji prasyarat meliputi uji normalitas dan homogenitas. Data yang dipakai adalah data dari hasil tes nilai siswa kelas IV (kelas kontrol) di SDN Tegalarum 2 dan kelas IV (kelas eksperimen) SDN 1 Pilangbango dengan jumlah soal angket minat belajar 20 soal. Kelas eksperimen adalah kelas yang mendapatkan perlakuan pembelajaran dengan media Big Book Writing, yaitu pada kelas V SDN 1 Pilangbangao Madiun. Pada waktu pelaksanaan tes keterampilan menulis dengan materi Lingkungan hidup, jumlah siswa kelas eksperimen adalah 20 siswa. Berdasarkan nilai tes keterampilan belajar siswa kelas eksperimen, data yang diperoleh dari objek penelitian pada kelas eksperimen yaitu jumlah siswa $(\mathrm{N})=20$ siswa; nilai tertinggi $=79$; nilai terendah $=$ $63 ;$ mean $=72,5 ;$ median $=73,5 ;$ modus $=$ 75; dan standar deviasi (s) $=4,664,66$. Data nilai yang diperoleh dari kelas eksperimen dapat disajikan dalam bentuk grafik sebagai berikut.
Berikut adalah hasil uji Normalitas dan Homogenitas. Uji normalitas digunakan untuk mengetahui apakah data sampel tersebut berasal dari populasi berdistribusi normal atau tidak. Pada penelitian ini peneliti menggunakan metode Lilliefors untuk uji normalitasnya, dengan taraf signifikansi $\propto=$ $\propto=0.05$. Daerah kritik pada uji ini adalah $\mathrm{DK}=\left\{\mathrm{LIL}>\mathrm{L}_{0.05 ; \mathrm{n}}\right\}$. Dari hasil analisis uji normalitas dengan kriteria ujinya adalah $\mathrm{H}_{\mathrm{o}}$ diterima/ $\mathrm{H}_{1}$ ditolak jika $\mathrm{L}_{\text {hitung }} \leq \mathrm{L}_{\text {tabel }}$ dan $\mathrm{H}_{\text {o }}$ ditolak/ $\mathrm{H}_{1}$ diterima jika $\mathrm{L}_{\text {hitung }}>\mathrm{L}_{\text {tabel }}$ untuk kelas kontrol $\mathrm{L}_{\text {hitung }}=0<0,200=\mathrm{L}_{\text {tabel }}$ maka $\mathrm{H}_{0}$ diterima, sehingga data yang diperoleh dari kelas kontrol berasal dari populasi yang berdistribusi normal. Adapun kelas eksperimen diketahui $\mathrm{L}_{\text {hitung }}=0,1185<0,190$ $=\mathrm{L}_{\text {tabel }}$ maka $\mathrm{H}_{0}$ diterima, sehingga data yang diperoleh dari kelas eksperimen berasal dari populasi yang berdistribusi normal.

Hasil analisis data uji normalitas kelas eksperimen dan kontrol dari data hasil post test disajikan dalam tabel berikut.

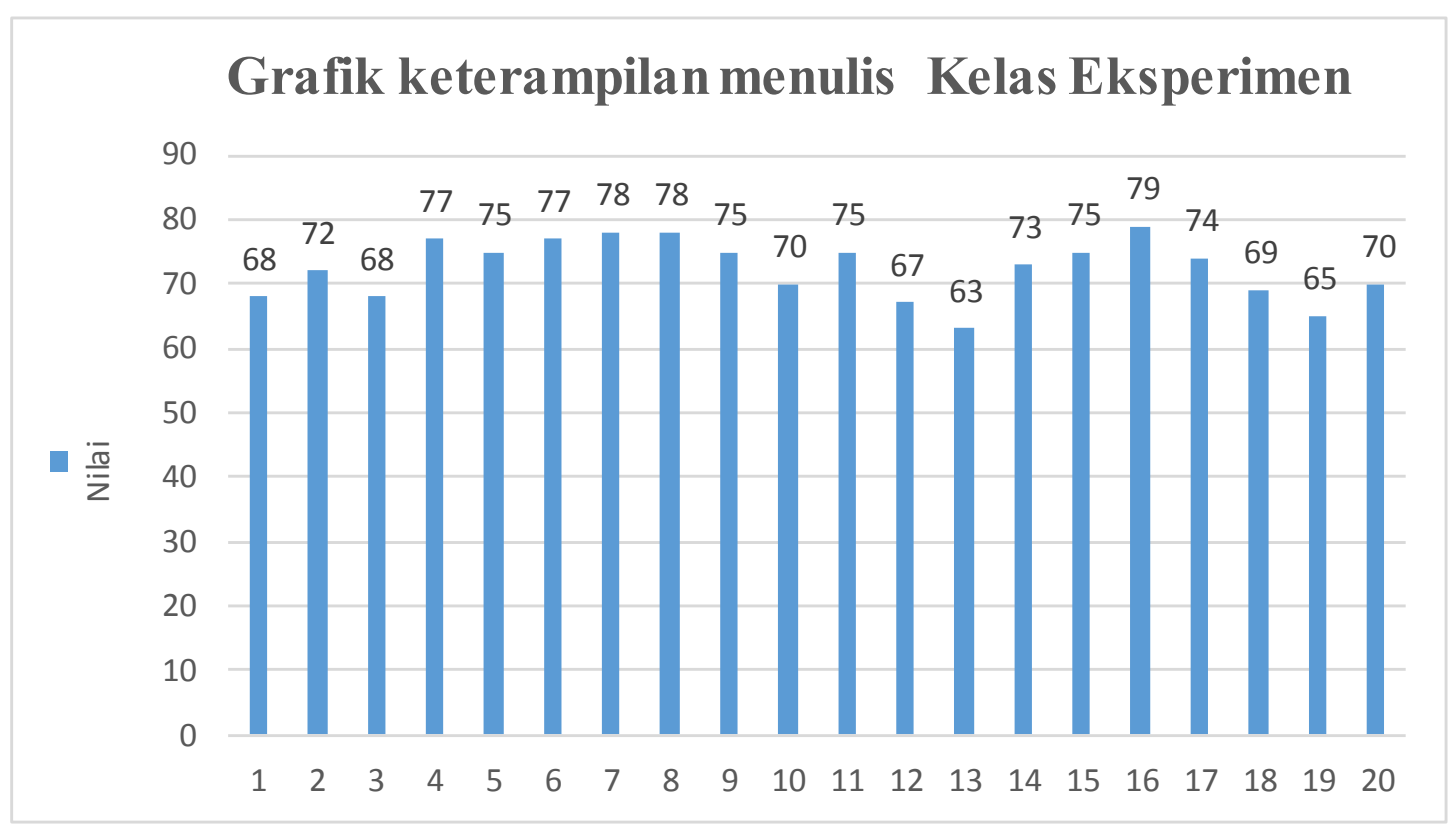




\begin{tabular}{|l|c|c|c|c|}
\hline \multicolumn{1}{|c|}{ Kelas } & $L_{\text {hitung }}$ & $L_{\text {tabel }}$ & KeputusanUji & Kesimpulan \\
\hline Kontrol & 0 & $\mathrm{~L}_{(0,05 ; 10)}=0,200$ & $\mathrm{H}_{0}$ diterima & Berdistribusi Normal \\
\hline Eksperimen & 0,1185 & $\mathrm{~L}_{(0,05 ; 20)}=0,190$ & $\mathrm{H}_{0}$ diterima & Berdistribusi Normal \\
\hline
\end{tabular}

Untuk analisis data uji homogenitas diperoleh $F_{\text {hitung }}=0,304$. Dengan kriteria pengujian $H_{o}=F_{\text {hitung }} \leq F_{\text {tabel }}, 0,304 \leq 2,20$. Ini berarti $H_{o}$ diterima, sehingga dapat disimpulkan sampel berasal dari populasi yang memiliki varians homogen.

\begin{tabular}{|c|c|c|c|}
\hline$F_{\text {hitung }}$ & $F_{\text {tabel }}$ & Kriteria & KeputusanUji \\
\hline 0,304 & $F_{0, \boldsymbol{O}(\mathbb{Q}, 9)}=2, \boldsymbol{D}$ & $F_{\text {hitung }} \leq F_{\text {tabel }}$ & $H_{o}$ diterima \\
\hline
\end{tabular}

Dari tabel di atas dapat dilihat bahwa hasil analisis data uji homogenitas diperoleh $F_{\text {hitung }}=0,304$. Dengan kriteria pengujian $H_{o}=F_{\text {hitung }} \leq F_{\text {tabel }}, 0,304 \leq 2,20$. Ini berarti $H_{o}$ diterima, sehingga dapat disimpulkan sampel berasal dari populasi yang memiliki varians homogen.

\section{Hasil Analisis Uji Hipotesis}

Setelah dipastikan data barasal dari populasi yang berdistribusi normal dan varians homogen, maka selanjutnya data diuji hipotesisnya dengan menggunakan uji-t dengan taraf signifikan $\alpha=0, \sigma$. Ada pengaruh media pembelajaran Bigbook Wrting terhadap minat belajar bahasa Indonesia pada siswa kelas IV SDN 1 Pilang Bangao Madiun tahun pelajaran 2015/2016.

Sesuai dengan uraian langkah-langkah pada uji hipotesis tersebut, maka dapat disimpulkan juga dengan tabel hasil analisis uji-t sebagai berikut.

\section{F. KESIMPULAN}

Penelitian tentang media pembelajaran Bigbook Writing memperoleh data hasil keterampilan menulis siswa kelas V SDN Tegalarum pada kelas kontrol atau kelas yang tidak diberi perlakuan dengan menggunakan media pembelajaran Bigbook Writing, hanya menggunakan media konvensional memiliki nilai rata-rata 67 , sedangkan kelas eksperimen atau kelas yang diberikan perlakuan dengan menggunakan media pembelajaran Bigbook Writing memiliki nilai rata-rata 73,5 .

Dari hasil analisis data tentang media pembelajaran Bigbook Writing terhadap keterampilan menulis siswa kelas $\mathrm{V}$ di atas, dapat diperoleh $t_{\text {hitung }}$ lebih besar dari $t_{\text {tabel }}$ yaitu $t_{\text {hitung }}>t_{\text {tabel }}$ atau 3,920>1,688 sehingga $H_{o}$ ditolak dan $H_{1}$ diterima. Dengan demikian dapat disimpulkan bahwa ada pengaruh positif

\begin{tabular}{|c|c|c|c|}
\hline Perlakuan & $\mathbf{T}_{\text {hitung }}$ & $\mathbf{t}_{\text {tabel }}$ & Keputusan \\
\hline Media Pembelajaran Big Book Writing & 3,920 & 1,688 & $\mathrm{H}_{0}$ Ditolak / $\mathrm{H}_{1}$ diterima \\
\hline
\end{tabular}


yang signifikan media pembelajaran Bigbook Writing terhadap keterampilan menulis pada siswa kelas V SDN 1 Pilangbango Madiun tahun pelajaran 2015/2016.

\section{G. DAFTAR PUSTAKA}

Arikunto, Suharsimi. (2013), Prosedur Penelitian: Suatu Pendekatan Praktik (Cetakan Kelima belas), Jakarta: Rineka Cipta.

Arsyad, Azhar. (2009), Media Pembelajaran, Jakarta: PT Grafindo Persada.

Depdiknas. (2006), Peraturan Menteri Pendidikan Nasional Nomor 22 Tahun 2006 Tentang Standar Isi untuk Satuan Pendidikan Dasar dan Menengah, Jakarta: Depdiknas.

Fitriani, Ika dan Bambang Yudi Cahyono. (2012), "The Effectiveness of Implementing Big-Book and NarrativeScaffold on the Students' Achievement in Writing Narrative Texts." Jurnal Universitas Negeri Malang (Vol. 1 Nomor 1). Hlm. 1-13

Lynch. (2008), A Guide for Using Big Books in the Classroom. Jurnal Scholastic Canada Ltd. Hlm. 1-6.

Nambiar, Mohana. (1993), "Early Reading Instruction-Big Books in the ESL Classroom." Jurnal The English Teacher (Vol XXII). Hlm. 1-7.

Rusman, Kurniawan, Deni, Riyana, Cepi. (2012), Pembelajaran Berbasis Teknologi Informasi dan Komunikasi Mengembangkan Profesionalitas Guru, Jakarta: Rajagrafindo Persada.

Suprihatiningrum, Jamil. (2013), Guru Professional, Yogyakarta: Delta Press.
Susilana, Rudi dan Cepi Riyana. (2008), Media Pembelajaran, Bandung: Jurusan Kurikulum dan Teknologi Pendidikan, FIP, UPI.

Suyanto, Kasihani K.E. (2007), English for Young Learners, Jakarta: PT Bumi Aksara.

Tarigan, H.G. (2008), Menulis Sebagai Suatu Keterampilan Berbahasa, Bandung: Angkasa Bandung. 
